\title{
Presentation and Echocardiographic Findings In Patients With Coarctation Of Aorta
}

\author{
Asmaa Ali Mohammed, somia had hood, Safaa Husein \\ Departments of Pediatrics, Faculty of Medicine, Sohag University
}

Type of article: Original.

\begin{abstract}
Background: Coarctation of the aorta (CoA) is a partial- or long-segment narrowing of the aorta, usually at the aortic isthmus, between the ductus arteriosus and the left subclavian artery.

Patients and methods: This was an observational cohort prospective study conducted at the Pediatric Department at Sohag University Hospital between July 2016 to July 2017. Full history, full clinical examination, Echocardiography were done for all included patients.

Results: The age range of presentation of CoA, was found to be 30 cases (60\%) presented during infancy, followed by 14 cases (28\%) at the age from 1-5 years, then 6 cases $(12 \%)$ after 5 years.

The clinical presentation of the studied cases were (54\%) of the patients presented with heart failure, 28 (56\%) cases presented with dyspnea, 32 (64\%) cases presented with loss of femoral pulse, all patients had a femoral radial delay and 21 $(42 \%)$ cases presented with hypertension.

Echocardiographic findings show that $58 \%$ of patients had left ventricular hypertrophy, $12 \%$ had hypoplasia of aortic arch, $22 \%$ had the bicuspid aortic valve, $18 \%$ had aortic stenosis. The associated cardiac congenital anomalies were $58 \%$ and $42 \%$ had no associated cardiac congenital anomalies.

Conclusion: Most cases of Coarctation of the aorta (CoA)presented during infancy, the most frequent symptoms were dyspnea and the most common sign is a femoral radial delay. Echocardiography is a noninvasive method and the one of choice in the diagnosis of Coarctation of the aorta.
\end{abstract}

Keywords: Coarctation of the aorta, early and late presentation, Echocardiographic findings.

\section{Introduction:}

Coarctation of the aorta $(\mathrm{CoA})$ is estimated by the Centers for Disease Control and Prevention to account for $4 \%-6 \%$ of all CHD in the United States, with a reported prevalence of 4 per 10000 live births. (1).

The presentation of coarctation can be in isolation or in association with other congenital heart anomalies. In some cases of long-standing coarctation, a compensatory collateral circulation develops from the internal thoracic and intercostal arteries, bypassing the coarctation to provide circulation to the lower extremities. (2)

Treatment and prognosis depend on the clinical state of disease: age, a 
clinical feature of the disease, associated anomalies, "simple CoA" or "mixed CoA", concomitant arch hypoplasia, hypertension, cerebral vascular involvement, etc (3).

We aimed to study the clinical profile of the Coarctation of the aorta (incidence,presentation,complication $\mathrm{s}$, echocardiographic finding) at the Pediatric Department at Sohag University Hospital (outpatient, inpatient, emergency department and neonatal intensive care unit).

\section{Patients and method:}

The present study had been performed at the pediatric department, outpatient clinic, intermediate care unit, and neonatal intensive care unit (NICU) of Sohag university hospital, Upper Egypt through the period from July 2016 to July 2017. It included 50 patients in the age category from birth to 15 years.

Inclusion criteria of patients: Any patient with a diagnosis of coarctation of aorta presented to our pediatric department during the period of study including both sexes. The age varies from birth to 15 years old.

Methods: All patients were subjected to:

- Complete medical history.

- Complete medical examination focusing on general and local cardiac examination.

- Echocardiography.

Statistical analysis:

Data were analyzed using IBM SPSS

Statistics for Windows version 22.

Quantitative data were expressed as means \pm standard deviation, median, and range. Qualitative data were expressed as number and percentage. The data were tested for normality using the Kolmogorov-Smirnov test and the Shapiro-Wilk test. The nonparametric Kruskal-Wallis test was used for data that wasn't normally distributed. A Chi-Square test was used for comparison between qualitative variables. A 5\% level was chosen as a level of significance in all statistical tests used in the study.

Ethical Consideration:

Consent was proved informally by a parent of patients in the Sohag Faculty of Medicine by the ethical Committee

\section{Results}

The study included 50 patients diagnosed by trans-thoracic two dimensional 2D, Doppler and color Doppler echocardio-graphy as coarctation of the aorta (COA). Records of these patients were analyzed for details of history, physical examination, and detailed echocardiography. Their ages ranged from 0 days to 15 years, as for gender distribution of the studied cases (50) 34 cases were males while 16 were femal with male predominance $68 \%$ of them. Table (1)

In our study we found that 30 cases $(60 \%)$ presented during infancy, followed by 14 cases $(28 \%)$ at the age from 1-5 years, then 6 cases $(12 \%)$ after 5 years. Table ( 1(

As regard to clinical presentation of the studied cases we found that (54\%) of the patients presented with heart failure, $28(56 \%)$ cases presented with dyspnea, 32 (64\%) cases presented with loss of femoral pulse, all patients had femoral radial delay and $21(42 \%)$ cases presented with hypertension. Table (2) According to echocardiographic findings our present study shows that $58 \%$ of patients had left ventricular hypertrophy, $12 \%$ had hypoplasia of aortic arch, 22\% had a bicuspid aortic valve, $18 \%$ had aortic stenosis and the mean of doppler gradient at coarctation (48.5 \pm 9.7). Table (3) 
OHAG MEDICAL JOURNAL Presentation and Echocardiographic Findings In Patients

It was found that $42 \%$ had no associated cardiac congenital anomalies and $58 \%$ of patients had associated cardiac congenital anomalies in the form of ASD, VSD in $14 \%$ each of them followed by PDA in $12 \%$ and others anomalies PFO, TGA, TR, MS, Complete A-V canal defect, PDA\&ASD, PDA\& VSD, Shone complex (AS, MS) and PDA, VSD\& DORV in $2 \%$ for each Table (4).

Table (1): Socio-demographic characteristics and weight of the studied cases(No. $=50$ ).

\begin{tabular}{|c|c|}
\hline Parameter & $\begin{array}{l}\text { Mean } \pm \text { S.D or } \\
\text { Number } \\
\text { (Frequency) }\end{array}$ \\
\hline $\begin{array}{l}\text { Age } \\
<1 \text { month } \\
1 \text { month }-<1 \\
\text { year } \\
1-5 \text { years } \\
>5 \text { years }\end{array}$ & $\begin{array}{l}\text { (Mean } \pm \text { S.D }=24.8 \\
\pm 37.4 \text { months) } \\
5(10 \%) \\
25(50 \%) \\
14(28 \%) \\
6(12 \%)\end{array}$ \\
\hline $\begin{array}{l}\text { Gender } \\
\text { Males } \\
\text { Females }\end{array}$ & $\begin{array}{l}34(68 \%) \\
16(32 \%)\end{array}$ \\
\hline
\end{tabular}

Table (2): Clinical presentation of the studied cases $($ No. $=50)$

\begin{tabular}{|l|l|}
\hline Parameter & $\begin{array}{c}\text { Number } \\
\text { Frequency }\end{array}$ \\
\hline Heart failure & and \\
No & $23(46)$ \\
Yes & $27(54)$ \\
\hline $\begin{array}{l}\text { Dyspnea } \\
\text { No } \\
\text { Yes }\end{array}$ & $22(44)$ \\
\hline $\begin{array}{l}\text { Loss of femoral } \\
\text { pulse }\end{array}$ & $28(56)$ \\
No & \\
Yes & $18(36)$ \\
\hline $\begin{array}{l}\text { Femoral radial } \\
\text { delay }\end{array}$ & $32(64)$ \\
No & \\
Yes & $0(0.0)$ \\
\hline $\begin{array}{l}\text { Hypertension } \\
\text { No }\end{array}$ & $\mathbf{5 0}(\mathbf{1 0 0})$ \\
Yes & $29(58)$ \\
\hline
\end{tabular}

Table (3): Echocardiographic findings of the studied cases. (No.=50).

\begin{tabular}{|c|c|}
\hline Parameter & Summary statistics \\
\hline $\begin{array}{l}\text { Left } \\
\text { ventricular } \\
\text { hypertrophy } \\
\text { No } \\
\text { Yes } \\
\end{array}$ & $\begin{array}{l}21(42 \%) \\
29(58 \%)\end{array}$ \\
\hline $\begin{array}{l}\text { Hypoplasia of } \\
\text { aortic arch } \\
\text { No } \\
\text { Yes } \\
\end{array}$ & $\begin{array}{l}44(88 \%) \\
6(12 \%)\end{array}$ \\
\hline $\begin{array}{l}\text { Bicuspid aortic } \\
\text { valve } \\
\text { No } \\
\text { Yes } \\
\end{array}$ & $\begin{array}{l}39(78 \%) \\
11(22 \%)\end{array}$ \\
\hline $\begin{array}{l}\text { Aortic Stenosis } \\
\text { No } \\
\text { Yes }\end{array}$ & $\begin{array}{l}41(82 \%) \\
9(18 \%)\end{array}$ \\
\hline $\begin{array}{l}\text { Doppler } \\
\text { gradient at the } \\
\text { coarctation } \\
\text { Mean } \pm \text { S.D. } \\
\text { Median } \\
\text { (Range) }\end{array}$ & $\begin{array}{l}48.5 \pm 9.7 \\
45.5(35-70)\end{array}$ \\
\hline
\end{tabular}

Table (4): Distribution of the studied cases according to associateed cardiac congenital anomalies (No. =50).

\begin{tabular}{|l|l|}
\hline Parameter & $\begin{array}{l}\text { Number and } \\
\text { Frequency }\end{array}$ \\
\hline ASD & $7(14)$ \\
\hline VSD & $7(14)$ \\
\hline PDA & $6(12)$ \\
\hline PFO & $1(2)$ \\
\hline TGA & $1(2)$ \\
\hline TR & $1(2)$ \\
\hline MS & $1(2)$ \\
\hline $\begin{array}{l}\text { Complete A-V } \\
\text { canal defect }\end{array}$ & $1(2)$ \\
\hline PDA, ASD & $1(2)$ \\
\hline PDA, VSD & $1(2)$ \\
\hline Shone complex & $1(2)$ \\
\hline $\begin{array}{l}\text { PDA, VSD, } \\
\text { DORV }\end{array}$ & $1(2)$ \\
\hline
\end{tabular}

(ASD: Atrial septal defect, VSD: Ventricular septal defect, PDA: Patent ductus arteriosus, PFO: Patent 
foramen ovale, TGA: Transposition of the great arteries, TR: Tricuspid regurge, MS: Mitral stenosis, A-V: Atrio-ventricular, DORV: double outlet right ventricle)

\section{Discussion:}

The present study had been performed at the pediatric department, outpatient clinic, intermediate care unit, and neonatal intensive care unit (NICU) of Sohag university hospital, Upper Egypt through the period from July 2016 to July 2017. It included 50 patients in the age category from birth to 15 years.

In this study, there was male predominance among total cases of $\operatorname{CoA}(50)$ males were 34 cases while 16 were females with male predominance $68 \%$ of them. This finding was in agreement with another study by Pedersen TAL et al they involved 246 patients underwent surgical repair of $\mathrm{CoA}$ with male predominance $63 \%$.(3)

In our study we found that most of the cases $30(60 \%)$ presented during infancy, followed by $14(28 \%)$ at the age from $1-5$ years, then $6(12 \%)$ after 5 years. These findings were highly in concordance with a study of Laohaprasitiporn, et al that found that the majority of the patients $(78.8 \%)$ were presented early within the first year of life. (4)

As regard to the clinical presentation of the studied cases, we found that 27 $(54 \%)$ of the patients presented with heart failure, $28(56 \%)$ had dyspnea, $32(64 \%)$ had loss of femoral pulse, all patients had femoral radial delay and $21(42 \%)$ had hypertension.

When comparing these findings with other results, our results are highly in concordance with Laohaprasitiporn et al. (4) that show the predominant clinical manifestations were congestive heart failure $(69.6 \%)$, systemic hypertension of the upper extremities $(36.3 \%)$ and decreased femoral pulses.

As regard presence of associated cardiac congenital anomalies the present study it was found that $58 \%$ of the patients had associated cardiac congenital anomalies (in the form of ASD, VSD $14 \%$ each of them followed by PDA in $12 \%$ and other anomalies PFO, TGA, TR, MS, Complete A-V canal defect, PDA and ASD, PDA and VSD, Shone complex (AR and MS) and PDA, VSD and DORV in $2 \%$ for each) and $42 \%$ had no associated cardiac congenital anomalies. These results correlate with Sun, et al series who stated that, there were 6 patients of CoA of solitary type and 47 patients with other intracardiac malformations, including, in descending order of frequency, PDA (54.7\%), VSD (43.4\%), ASD (35.8\%) and TAPVD (1.9\%). (5)

In the current study, we found that $6 \%$ of patients had noncardiac congenital anomalies in the form of Down syndrome, Turner syndrome and hypertelorism, cleft palate, small mandible, protruded mandible for $2 \%$ of patients each. This is consistent with a study done by Malcic et al. (6) who stated that $20(9.95 \%)$ patients, coarctation were found within the known syndromes (Turner, Noonan, Williams Beuren, Ellis van Creveld, Down, partial trisomy 18, fetal valproate syndrome).

\section{Conclusion:}

Most cases of Coarctation of the aorta30 (60\%) presented during infancy, the most frequent symptom was dyspnea, the most common sign is a femoral radial delay and the less common sign was hypertension.

Echocardiography is a noninvasive method and the one of choice in the 
diagnosis of Coarctation of the aorta and presence of other associated cardiac congenital anomalies.

\section{Acknowledgment:}

Authors thank colleagues in the pediatric department, faculty of medicine, Sohag university (Egypt) for their assistance.

\section{Author's contributions:}

All authors contributed to this project and article equally. All authors read and approved the final manuscript.

\section{References:}

1. Kailin JA, Santos AB, Furtun BY(2017) Isolated coarctation of the aorta in the fetus: A diagnostic challenge. Echocardiography.;34:1768-1775.

2. Aboulhosn J, Child JS. (2015) Echocardiographic evaluation of congenital left ventricular outflow obstruction. Echocardiography (Mount Kisco, NY).;32Suppl 2: S140-7.

3. Pedersen TAL, Munk K, Andersen NH, et al. (2011)High Long-term Morbidity in Repaired Aortic Coarctation. Congenit Heart Dis.;6:573582.
4. Laohaprasitiporn D, Jarucharoenporn S, Nana A (2000)Coarctation of the aorta in children at Siriraj Hospital.J Med Assoc Thai. Nov;83Suppl 2: S89-97.

5. Sun Z, Cheng TO, Li L.(2015) Diagnostic Value of Transthoracic Echocardiography in Patients with Coarctation of Aorta: The Chinese Experience in 53 Patients Studied between 2008 and 2012 in One Major Medical Center. PLoSONE .;10(6): e0127399.

6. Malcic I, Kniewaid H, Jelic A, Saric D, Bartonicek D, Dilber D, Belina D, Anic D (2015) Coarctation of the aorta in children in the 10- year epidemiological study: diagnostic and therapeutic consideration. LijecVjesn. 2015 JanFeb;137(1-2):9-17. 